\title{
Footprint of Personality Characteristics on Financing Objectives: The Arbitrating capacity of Risk Attitude and the Moderating capacity of Investment Savvy
}

\author{
Javed Hussain, Tariq Mehmood Dar, and Neelofer Tariq
}

\section{ABSTRACT}

The following study clarifies the role of risk attitude in revolving the relationship between Financing Objectives and personality characteristics and the moderating role of investment savvy between risk attitude and financing objectives by the particular sample size of 200 students. The participants of the study belonged from finance background. To simplify the collected data, the regression analyses was utilized in a flow to implicate the effect upon the dependent variables of the independent variables. To get more enhanced results, the mediator and the moderator were uplifted. Hence by, the results revealed that individuals who are activity, determined, and sympathy towards others are more willing to opt for STFO (short term financing objectives). Whilst, in long run extraversion, openness to experience and agreeableness, and conscientiousness traits are more inclined towards LTFO (long term financing objectives).

Moreover, the study further mentions that STFO and LTFO are not much affected by investment savvy of an individuals. Nonetheless, the investment savvy is not really bothered by the relationship of financing objectives and risk attitude.

Keywords: Financing Objectives, Investment savvy, Personality Characteristics, Risk attitude.

\section{INTRODUCTION}

Given ambiguity and uncertainty in decision making, the conventional financial paradigm rests on cognitive prejudice [1]. However, behavioral financing, a novel paradigm, undermines the argument of rationality of conventional financial paradigms by demonstrating how personal and situational variables impact the investment decision of an investor. The study shows that these traits affect a person's perception of financial risk, which in turn impacts their behavior in financing [2]. Risk acceptance being a vital aspect to consider while making financial decisions, saving, and investing. Financial managers often analyze individual risk attitude to predict investment place behaviour [3]. This is considered as essential to accurately evaluate the probability tolerance of a customer and assign portfolios. Regardless of the importance of risk attitude, behavioral and mental variables might influence decision-making [4].

Researchers discovered a variety of behavioral variables, including demographics, as a result of their findings. Lusardi and Alessie [5] examined investment savvy, while they researched personality. These variables affect not just the decisions of a person, but their risk-taking behaviour. The planned behavior theory (PBT) examines several context elements (personality, socio-economic status, sex, age, ethnicity, education, and previous experiences) that may affect people's behavior and therefore their stance on action

\author{
Submitted : July 02*, 2021 \\ Published : July 24, 2021 \\ ISSN: 2507-1076 \\ DOI: $10.24018 /$ ejbmr.2021.6.4.971 \\ Javed Hussain * \\ Assistant Professor, Muhammad Ali \\ Jinnah University, Karachi, Pakistan, PhD \\ Scholar, University of Karachi, Pakistan. \\ (e-mail: javed.hussain@jinnah.edu) \\ Tariq Mehmood Dar \\ Director Marketing \& Sales \\ Pharmaceuticals, UAE/Pakistan. \\ (e-mail: drtariqdar@gmail.com) \\ Neelofer Tariq \\ Professional Sales \& Marketing Trainer, \\ UAE/Pakistan \\ (e-mail: neelofer.hanif@gmail.com) \\ *Corresponding Author
}

and objective [6]. The idea of intended behavior is, nonetheless, not used for analyzing individual Financing Objectivess that depend on these features. The present study thus examines the essential background elements of the personality and investment savvy of an individual, in order to better understand the underlying causes behind each financing objectives. According to the definition, "personality" is "the way an individual interacts, reacts, and behaves with others, which is frequently manifested through quantifiable traits" [7]. The objective of evaluating investment savvy is to determine if it influences financing objectives. The aim of this survey is to assess the character of risk attitude in the connection between character and financing objectives, as well as the effect of risk attitude and financing objectives on investment savvy. "Investment savvy has the potential to significantly alter migrant behavior" says Rispens [8]. The interest of politicians and university students in investment savvy has been highlighted by its relevance in making investment decisions [9].

\section{LITERATURE REVIEW}

\section{A. Personality Characteristics}

The manner of interaction, responds, and conduct described as "the way an individual interacts, reacts and acts with others, and is usually described by measurable features" 
[7]. However, Allport and Odbert's [10] "Big Five Factor Model" is considered as often utilized classification. Openness to new experiences, extraversion, self-awareness, and conviviality are all part of the idea. Personal characteristics including cognitive, motivational, and emotional components influenced a wide range of decisions [11]. "Personalities of investors are linked to their investment choices and results" [12].

\section{B. Personality Characteristics and Financing Objectives}

\section{1) Extraversion and Financing Objectives}

"Active, optimistic, exciting and socializing in large crowds" is how extraversion is characterized [13], [14]. As per Pan [15], "extraversion only has positive information that influences their assessment of success and creates excessive trust in financial decision-making". In a study of business school graduates, Mayfield et al. [2] revealed that they frequently engage in the extraversion trade and prefer to invest in equities. He also shows that extraversion and risk aversion have a negative connection. Another study of the relationship between personality and household financial decisions found that "extroversion is linked to unsecured debts and financial assets" [16]. "Those with higher extraversion levels appear to be more likely to achieve greater returns" (As per [12]). Hence,

$H_{1}[a]:$ Extraversion is linked to a positive outlook on financing.

\section{2) Neuroticism \& Financing Objectives}

Neurotic personalities are "pessimistic, depressed, concerned and more afraid of insecurity and ambiguity" [17]. Worried personalities are typically risk cautious \& prefer low-risk investments [18]. Neurotic persons seek predictability and shun foreign equities and debt products, according to Niszczota [19]. In neurotic persons, analytical ability, critical thinking, cognitive capacities, and conceptual comprehension are all weak. These flaws add to neurotics' fear of failure and anxiety while making risky decisions [20]. Neuroticism \& risky behavior are linked, according to Pak and Mahmood [21]. Neurotic persons exaggerate the benefits of a positive market climate while exaggerating the hazards of a bad market climate. According to another study, "risk taking behaviour, when making risky choices, is related to neurological impairments, those with low neuroticism are more concerned" [22]. As a result, we assume:

$H_{1}[b]:$ Neuroticism possesses an unfavorable influence over incentive to invest.

\section{3) Agreeableness \& Financing Objectives}

According to Mayfield et a. [2], agreeableness is linked to altruism, individual affection, compassion, helpfulness for others. People that are nice do not engage in conflict with others. They believe what others tell them without questioning it [7]. Furthermore, pleased investors' trading activity revealed that "they are intensively following market behavior and trading stocks" [23]. Consent and risky behavior have a negative connection, according to Pak and Mahmood [21]. Individuals who are agreeable rely on financial professionals' guidance and have difficulty making their own financial judgments. As a result, we believe:

$H_{1}[c]:$ The capacity to reach an agreement influences investment intent positively.

\section{4) Openness to Experience and Financing Objectives}

This personality attribute is associated with creative personalities, who are intellectual, and generous [24]. Such persons possess a natural interest in aesthetics, current events, and novel concepts [25]. According to the report, "positive impact on long-term investment in US undergraduate business schools" [2]. Those who are more receptive to new ideas are at a higher risk than their colleagues, according to Nandan and Saurabh [26]. "Openness in people promotes greater readiness to adopt unconventional thumb rules prescribed in financial decision making." Nga and Ken Yien are the authors of this piece [1]. These individuals are confident in their peril lenience and are positive to finance in the financial market. As a result, we assume:

$H_{1}[d]$ : Openness possesses a favorable impression on Financing Objectives.

\section{5) Conscientious \& Financing Objectives}

"Defined, well-organized, reliable, persistent, punctilious and risky" are characteristics of conscientious people [2]. People who are conscientious make informed judgments [25]. Individual awareness enhances trading habits and encourages traders to make more transactions in order to achieve their goals [27]. Conscientious investors are not fooled, and they make sound investment decisions. This ability allows people to be more cautious in their financial decisions \& risk acceptance [28]. According to Mahmood et al. [21], conscientiousness and financial risk tolerance have a negative connection.

$H_{1}[$ e]: Increasing investment awareness has a favorable effect on Financing Objectives.

\section{Personality Characteristics and Risk Behaviour}

This personality attribute is associated with those who are creative, intellectual, \& generous [24]. Such personalities possess a natural interest in aesthetics, current events, and novel concepts [25]. According to the report, "positive impact on long-term investment in US undergraduate business schools" [2]. Those who are more receptive to new ideas are at a higher risk than their colleagues, according to Nandan and Saurabh [26]. "Openness in people promotes greater readiness to adopt unconventional thumb rules prescribed in financial decision making." Nga and Ken Yien are the authors of this piece [1]. These individuals are confident in their risk tolerance and are inclined to finance in the financial market. As a result, we assume:

$\mathrm{H}_{2}$ : Personality characteristics possess an influence on risk attitude. 


\section{Risk Attitude and Financing Objectives}

"People have a certain target risk level according to the theory of risk homeostasis and, in order to reach that level, participate in activities with the highest net profit balance over losses" [30]. Peril has a significant influence on investment behavior [31]. According to Keller [32], an investor's "financial risk tolerance, revenue level and investment account." all had a substantial influence. Investors' risk tolerance is divided into three categories by Wanyana [33]: less risk, average risk, \& strong risk. Wanyana [33] divides financers into two groups: those who choose to store cash and bonds [3] and those who trade stocks and derivatives [34]. Risk aversion has previously been believed to be the polar opposite of risk tolerance [35]. The study discovered a connection between risk aversion and inclination for investing [36]. As a result, following assumption is made:

\section{$H_{3}:$ Investment intent is influenced by risk attitude.}

\section{E. The Mediating Role of Risk Attitude}

The willingness to invest is implied by the subject's purpose to conduct. This is linked to a person's risk appetite and financial resources [37]. Individual risk attitude was used to create risk evaluations. Negative behavior resulted in an overestimation of risk, resulting in the loss of a lucrative opportunity [38]. Equities, or stocks, are often invested in by investors with a well-balanced portfolio [32]. Cash and bonds are kept on hand by people who have a low risk tolerance [3]. According to Nandan and Saurabh (2016), "risk attitude functions as a mediator between people's personality characteristics and their short- and long-term Financing Objectivess." Nandan and Saurabh [26] also observed that "Both the relationship between neuroticism and short-term Financing Objectives and the relationship between extraversion and short-term Financing Objectives were mediated by risk attitude. On the other hand, risk attitude did not function as a link between personality characteristics and long-term tenure investment." According to Mahmood [29], people's risk tolerance behavior is impacted by their Personality Characteristics. We assumed the following based on our discussion:

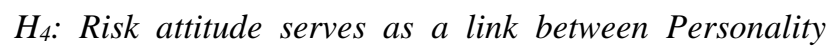
Characteristics and investing goals.

\section{F. The Moderating Role of Investment savvy}

Investment savvy is defined as the "capability to make informed decisions and decide effectively how to use and manage money" [39]. Investment savvy is piqued the interest of politicians and academics due to its importance in financial decisions [9]. Making smart investment decisions and preserving long-term financial security need financial knowledge. Many people avoided investing due to a lack of financial knowledge [40]. Investment savvy, according to one study, allows investors to manage their assets and optimize investment returns [5]. Investment savvy, according to [8], has the capacity to affect migrants' behavior [40]. Investment savvy and sound financial decision-making are inextricably connected [42]. Higher investment savvy, according to the study, improves a person's chance of investing in the stock market [5]. Individuals with little or no experience with investment methodology are least to take part in stock markets or financial institutions [43]. Investment savvy is essential not just for financial conduct but also for risk attitude. When making investing selections, risk tolerance and financial competence are key aspects to consider [44]. According to the study, those with a lower level of financial and investment savvy have a different view on financial risks. Financial experts favor riskier investment sectors to less financially savvy individuals [45]. People who are inexperienced with investment methodology are less likely to participate in the financial market, according to one study [43]. People with a greater degree of financial awareness had a reduced sense of financial dangers and a stronger desire to invest, according to Weber and Milliman (1997). In addition, the study discovered that people's perceptions of risk deterrence affected their decision to preserve assets. People exhibit financing know-how with skills had lower peril sensitivity and more trading desire, according to another study, indicating similar consequences [46].

$H_{5}$ : In the relationship between risk-taking behavior and Financing Objectives, investment savvy acts as a moderator.

\section{G. Theoretical Framework}

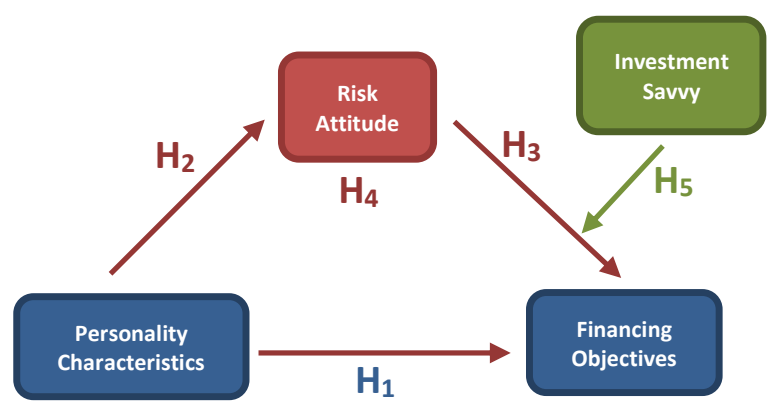

Fig. 1. Theoretical Framework.

The study's theoretical framework, which is based on the study's aim, is depicted in the first image. The general theoretical framework is derived from the literature review. Personality characteristics are considered as a separate variable in this study, whereas financing objective is handled as a dependent variable. Risk attitude is viewed as a mediating variable since each personality feature is linked to a financial risk attitude that may impact an individual's inclination to invest [26]. They are less concerned about financial danger and more focused on investing, in addition to having a superior financial awareness [46]. As a result, investment savvy is increasingly being recognized as a mitigating factor in the link between risky conduct and investment intent. Individuals' financing objectives are divided into short-term and long-term financings [2]. 


\section{RESEARCH METHODOLOGY}

\section{A. The Sample \& the Statistics}

Students from different universities participated in the present study as undergraduate and graduate business students. Strategic finance, accounting and investment analysis are among the subjects covered by these students. Due to their expected degree of financial experience, these students can provide answers to financing decision-making issues [47].

\section{B. Measurements and Concepts}

\section{1) Independent Variable}

In this study, the "Big five characteristic traits" were used as independent variables ("neuroticism, extroversion conscientiousness, agreeability and openness to experience"). Mayfield et al. [2] used questions from a prior study to measure personality characteristics. The intention to invest in people is used as a dependent variable. The following details were taken from the Mayfield et al. [2] study. Queries were asked about "short-term financing objectives" and "long-term financing objectives." Individual responses to each statement were graded on a "five-point scale" with "complete disagreement" being the lowest and "strong agreement" being the highest.

As a dependent variable, individual financing objectives are used. The following details were taken from the Mayfield et al. study [2]. Respondents' "short-term investment intent," was assessed using five questions, while their "long-term Financing Objectives" was assessed using five questions. Individual responses to each statement were graded on a "five-point scale" with "complete disagreement" being the lowest and "strong agreement" being the highest.

\section{2) Moderation-related variable}

Investment savvy is used as a moderating variable in this study. Van Rooij et al. [48] developed a questionnaire to assess studies on investment savvy. Questionnaire assesses a person's grasp of concepts such as "numeration, compounding interest, inflation, money time and cash illusion." This study only focuses at one component of investment savvy, namely the fundamental level.

\section{3) Mediation- related Variable}

In the current study, risk attitude is used as a mediating variable. To quantify "risk attitude" use Mayfield et al. [2] four components. The measurement points were determined using a "five-point Likert scale. A high score indicates a person's tendency to shun financial risks associated with possibly beneficial ventures (negative conduct).

\section{Analysis of Findings}

Regression analysis was run to analyze how the independent variable influenced the dependent variable. Furthermore, mediator and moderator model were used in the study to provide more vivid results. SPSS-25 was used to analyze the data for this investigation.

\section{EXPLANATORY FINDINGS}

More than half of students provide a written response to the question "numeration, interest compounding, inflation and the financial illusion" indicating that they have basic investment savvy. However, more than half of the pupils were unable to correctly answer the question on money's time value.

\begin{tabular}{cccccc}
\multicolumn{5}{c}{ TABLE I: FUnDAMENTAL INVESTMENT SAVVY } \\
\hline Components & Numeracy & $\begin{array}{c}\text { Interest } \\
\text { Compounding }\end{array}$ & Inflation & $\begin{array}{c}\text { Time Value } \\
\text { of Money }\end{array}$ & $\begin{array}{c}\text { Money } \\
\text { Illusion }\end{array}$ \\
\hline Correct & $86.5 \%$ & $43.5 \%$ & $66.5 \%$ & $46.0 \%$ & $55.5 \%$ \\
$\begin{array}{c}\text { Incorrect / Do not Know } \\
\text { Total }\end{array}$ & $13.5 \%$ & $56.5 \%$ & $33.5 \%$ & $54.0 \%$ & $44.5 \%$ \\
\hline
\end{tabular}

\section{A. Reliability}

The instrument's reliability was first assessed. In order to attain consistency, the dependability coefficient must be between 0.5 and 0.8 , according to study [49]. The "Cronbach alpha coefficient" of this instrument is more than 0.50 , indicating its reliability.

\begin{tabular}{ccc}
\multicolumn{3}{c}{ TABLE II: RELIABILITY } \\
Scale & $\begin{array}{c}\text { No. of } \\
\text { Items }\end{array}$ & $\begin{array}{c}\text { Cronbach's } \\
\text { Alpha }\end{array}$ \\
\hline Investment Savvy & 5 & 0.928 \\
Risk Attitude & 6 & 0.944 \\
Extraversion & 4 & 0.923 \\
Neuroticism & 5 & 0.940 \\
Agreeableness & 4 & 0.923 \\
Openness to Experience & 5 & 0.956 \\
Conscientious & 5 & 0.940 \\
Short term financing objectives & 5 & 0.895 \\
Long term financing objectives & 5 & 0.944 \\
\hline
\end{tabular}

\section{B. Correlation Analysis}

Creating a link between all of the variables in the study the correlation was done with SPSS, and the results are shown in Table III. Extraversion and STFO $\left(=0.578^{* *}\right)$ and LTFO
$(=0.654 * *)$ have a strong positive connection, according to the data. STFO (=-0.212**) and LTFO (=-0.120*) had a substantial inverse association with neuroticism. Other Personality characteristics that STFO and LTFO have been found to improve include "Agreeableness" (=0.631**, $0.754 * *)$, "Openness to Experience" $\left(=0.553^{* *}, 0.648^{* *}\right)$, and "Conscientious" $\left(=0.785^{* *}, 0.759 * *\right)$. STFO and LTFO have a strong relationship with investment savvy $\left(=0.611^{*}\right.$, $0.521 * *)$.

\section{Regression Analysis}

The following hypotheses were tested using regression analysis utilizing the OLS method. Those with the personality characteristics "Extraversion," "Agreeability" and "Awareness (Conscientious)" had a decreased risk of STFO, according to the preliminary regression analysis. According to this research, those who are active, sympathetic toward others, driven, and well-organized are more likely to acquire STFO. People with the personality characteristics "Extraversion" LTFO, according to the second regression result. People who are engaged, dedicated, and wellorganized are better prepared for LTFO, according to these 
findings. "Investment savvy had no significant effect on LTFO and STFO. These findings indicate that providing investment savvy education can motivate people to participate in LTFO. For risk (negative) behavior, significant negative STFO and LTFO correlations have been discovered.

\begin{tabular}{|c|c|c|c|c|c|c|c|c|c|}
\hline Components & IS & RA & EXT & $\mathrm{NEU}$ & AGR & $\mathrm{OE}$ & $\mathrm{CON}$ & STFO & LTFO \\
\hline IS & 1 & & & & & & & & \\
\hline RA & $-0.497 * *$ & 1 & & & & & & & \\
\hline EXT & $0.711 * *$ & $-0.458 * *$ & 1 & & & & & & \\
\hline NEU & $-0.231 * *$ & $0.441 * *$ & $-0.323 * *$ & 1 & & & & & \\
\hline AGR & $0.511^{* *}$ & $-0.421 * *$ & $0.643 * *$ & $-0.022 * *$ & 1 & & & & \\
\hline $\mathrm{OE}$ & $0.751 * *$ & $-0.523 * *$ & $0.755 * *$ & $-0.034 * *$ & $0.755^{* *} *$ & 1 & & & \\
\hline $\mathrm{CON}$ & $0.460 * *$ & $0.741 * *$ & $0.543 * *$ & $-0.045^{* *}$ & $0.760 * *$ & $0.487 * *$ & 1 & & \\
\hline STFO & $0.611 * *$ & $0.659 * *$ & $0.578 * *$ & $-0.212 * *$ & $0.631 * *$ & $0.553 * *$ & $0.785 * *$ & 1 & \\
\hline LTFO & $0.521 * *$ & $0.709 * *$ & $0.654 * *$ & $-0.120 *$ & $0.754 * *$ & $0.648 * *$ & $0.759 * *$ & $0.639 * *$ & 1 \\
\hline
\end{tabular}

Where "EXT = Extraversion, NEU = neuroticism, AGR = agreeableness, OE = openness to expertise, CON = Conscientious, IS = Investment Savvy, RA = Risk Attitude, STFO = Short Term Financing Objectives, LTFO= Long Term Financing Objectives".

TABLE IV: REGRESSION ANALYSIS

\begin{tabular}{ccccc}
\multicolumn{5}{c}{ TABLE IV: REGRESSION ANALYSIS } \\
\hline (Constant) & B & Std. Error & t-value & Sig. \\
EXT & 0.100 & 0.032 & 7.675 & 0.000 \\
NEU & -0.052 & 0.072 & 2.324 & 0.021 \\
AGR & 0.265 & 0.058 & -1.68 & 0.055 \\
OE & -0.057 & 0.055 & -1.01 & 0.310 \\
CON & 0.399 & 0.058 & 6.610 & 0.000 \\
IS & 0.430 & 0.056 & 1.420 & 0.031 \\
RA & $0-.023$ & 0.074 & -5.01 & 0.010 \\
\hline
\end{tabular}

Dependent variable: STFO.

TABLE V: REGRESSION ANALYSIS

\begin{tabular}{|c|c|c|c|c|}
\hline & B & Std. Error & t-value & Sig. \\
\hline (Constant) & 2.281 & 0.036 & 6.18 & 0.000 \\
\hline EXT & 0.100 & 0.041 & 2.11 & 0.012 \\
\hline NEU & 0.011 & 0.011 & 0.410 & 0.450 \\
\hline AGR & 0.134 & 0.035 & 0.490 & 0.510 \\
\hline $\mathrm{OE}$ & -0.012 & 0.024 & -0.059 & 0.410 \\
\hline $\mathrm{CON}$ & 0.240 & 0.065 & 5.43 & 0.000 \\
\hline IS & 0.356 & 0.112 & 1.11 & 0.010 \\
\hline RA & -0.021 & 0.039 & -5.38 & 0.010 \\
\hline
\end{tabular}

Dependent variable: LTFO.

D. Mediation \& Moderation Analysis

TABLE VI: MEDIATION AND MODERATION IMPACT

\begin{tabular}{cccccc}
\hline \multirow{2}{*}{ Objectives } & $\begin{array}{c}\text { Original } \\
\text { Sample } \\
(\mathrm{O})\end{array}$ & $\begin{array}{c}\text { Sample } \\
\text { Mean } \\
(\mathrm{M})\end{array}$ & $\begin{array}{c}\text { Stand. } \\
\text { Dev. } \\
(\text { ST.DEV.) }\end{array}$ & $\begin{array}{c}\text { Stand. } \\
\text { Err. } \\
\text { (ST.ERR.) }\end{array}$ & $\begin{array}{c}\text { T } \\
\text { Statistics }\end{array}$ \\
\hline IS -> FO & 0.131 & 0.132 & 0.093 & 0.093 & 1.416 \\
PC -> FO & 0.743 & 0.744 & 0.087 & 0.087 & 8.549 \\
PC -> RA & 0.76 & 0.757 & 0.041 & 0.041 & 18.535 \\
RA -> FO & 0.207 & 0.207 & 0.07 & 0.07 & 2.973 \\
\hline
\end{tabular}

IS = Investment Savvy; PC = Personality Characteristics, FO = Financial Objectives; RA = Risk Attitude.

Table VI depicts that the impact of investment savvy is not significant on financial objectives as moderator. Though rest of the variables showed significant impact (PC-FO; PC-RA; RA-FO).

\section{CONCLUSION AND DISCUSSION}

With the amalgamation of both investment savvy and risk attitude our study linked the impacts of investment savvy and risk attitude to unleash the Financing Objectives amongst individuals with multiple personalities and respective characteristics.

The role of risk attitude practiced by individuals as a matter of impact from their Personality Characteristics and their intention to invest is observed with the help of the following study. Lastly, the study helps to discover the fact that the level of investment savvy fluctuates the coordination of Financing Objectives and risk attitude.

Further, individual's intention regarding investment were clearly understood by dividing them into long term and shortterm financial goals revealed as "Short term Financing Objectives". Whilst the individuals who want to pursue long run financing aims were disclosed with "long term financing objectives" [2].

The results discovered that individuals who maintain the Personality Characteristics of "Extraversion", "Agreeableness" and "Conscientious" throw an imperative impact on STFO. Individuals' who stay active, show more sympathy towards to others, show well-organized behaviors, stay determined want to pursue short term financial goals and are more inclined towards STFO. Whilst individuals who have traits such as "Extraversion'" showed an imperative impact on LTFO.

The study also relates to an extent the relationship of personality characteristics with STFO. Whilst, in Long term risk aversion the association of EXT, AGR, OE \& CON with LTFO nonetheless, quite with Neuroticism.

The study revealed that investment savvy does not moderately impact the STFO and LTFO relationship with Risk aversion and also not on financing objectives.

\section{IMPLICATIONS OF THE RESEARCH}

The following study showed the role of Personality Characteristics, risk attitude and level of investment savvy upon Financing Objectives of individuals (students). The study could have focused on financial managers, public servants (governmental personnel) that are held responsible for financial bargaining, and financial institutions as well to get their validated results on the results. Moreover, as the study was being practiced in the geographical territory of Pakistan-Karachi, it must be extended to other cities as well in future. Financial Literacy programme can be inculcated as a result of outcome of this study along with collaboration with output from financial institutions. Lastly, the study commented upon that financial managers and investment advisors should also focus on financial risk attitude and personality characteristics to individuals while giving direction to them. 


\section{FUTURE RESEARCH CHALLENGES AND DIRECTIONS}

Along with valuable implications, the study present some of the restrictions or limitations that can be validated for the concerning ones. The fore most limitation is in the manner that the study was focused on Pakistan only and hence data collection as conducted in the territory only which is why generalization needs to be analyzed before implementation. Afterwards, the study is only related to Personality Characteristics and ignores physiological traits, behavioral traits and demographic traits that could increase the potential value of the study by combining with Financing Objectives and risk attitudes. Likewise, future studies must consider the missing elements of the under consideration study.

Lastly, the data collection of the following study was limited to a very restrained side and only four universities were asked to participate in the study. Thereby, the future studies must focus on increasing the population size and also the variety of universities, so as to include different traits individuals.

\section{REFERENCES}

[1] Nga, J. K., \& Ken Yien, L. (2013). The influence of personality trait and demographics on financial decision making among Generation Y. Young Consumers, 14(3), 230-243.

[2] Mayfield, C., Perdue, G., \& Wooten, K. (2008). Investment management and personality type. Financial Services Review, 17(3), 219-237.

[3] Grable, J. E., \& Lytton, R. H. (2003). The development of a risk assessment instrument: A follow-up study. Financial Services Review, 12(3), 257-275.

[4] Kourtidis, D., Sevi `c, ' Z., \& Chatzoglou, P. (2011). Investors' trading activity: A behavioural ${ }^{`}$ perspective and empirical results. The Journal of Socio-Economics, 40(5), 548-557.

[5] Lusardi, A., \& Mitchell, O. S. (2008). Planning and financial literacy: How do women fare? American Economic Review, 98(2), 413-417.

[6] Ajzen, I. (2002). Perceived behavioral control, self-efficacy, locus of control, and the theory of planned behavior. Journal of Applied Social Psychology, 32(4), 665-683.

[7] Costa, P. T., \& McCrae, R. R. (1992). NEO PI-R professional manual, psychological assessment resources. Odessa: TX. Crysel, L. C., Crosier, B. S., \& Webster, G. D. (2013). The dark triad and risk behavior. Personality and Individual Differences, 54(1), 35-40.

[8] Rispens. (2013). Financial literacy and financial inclusion of migrant workers: The case of Indian migrant workers in Qatar.

[9] Aren, S., \& Aydemir, S. D. (2014). A literature review on financial literacy. Journal of Financial Researches and Studies, 5(11), 33-49.

[10] Allport, G. W., \& Odbert, H. S. (1936). Trait-names: A psycho-lexical study. Psychological Monographs, 47(1). doi: 10.1037/h0093360.

[11] Dolan, P., Elliott, A., Metcalfe, R., \& Vlaev, I. (2012). Influencing financial behavior: From changing minds to changing contexts. Journal of Behavioral Finance, 13(2), 126-142.

[12] Durand, R. B., Newby, R., \& Sanghani, J. (2008). An intimate portrait of the individual investor. The Journal of Behavioral Finance, 9(4), 193-208.

[13] Leary, M. M., Reilly, M. D., \& Brown, F. W. (2009). A study of personality preferences and emotional intelligence. Leadership \& Organization Development Journal, 30(5), 421- 434.

[14] McCrae, R. R., \& Costa J, P. T. (1997). Personality trait structure as a human universal. American Psychologist, 52(5), 509-516.

[15] Pan, C. H., \& Statman, M. (2013). Investor personality in investor questionnaires. Journal of Investment Consulting, 14(1), 48-56.

[16] Brown, S., \& Taylor, K. (2014). Household finances and the "big five'personality traits. Journal of Economic Psychology, 45, 197-212.

[17] Migliore, L. A. (2011). Relation between big five personality traits and Hofstede's cultural dimensions: Samples from the USA and India. Cross Cultural Management: An International Journal, 18(1), 38-54.

[18] Gambetti, E., \& Giusberti, F. (2012). The effect of anger and anxiety traits on investment decisions. Journal of Economic Psychology, 33(6), 1059-1069.

[19] Niszczota, P. (2014). Neuroticism, uncertainty, and foreign investment. Pozna 'n University of Economics (Working Paper).
[20] Young, S., Gudjonsson, G. H., Carter, P., Terry, R., \& Morris, R. (2012). Simulation of risk-taking and it relationship with personality. Personality and Individual Differences, 53(3), 294-299.

[21] Pak, O., \& Mahmood, M. (2015). Impact of personality on risk tolerance and investment decisions: A study on potential investors of Kazakhstan. International Journal of Commerce and Management, 25(4), 370-384

[22] Vigil-Colet, A. (2007). Impulsivity and decision making in the balloon analogue risktaking task. Personality and Individual Differences, 43(1), 37-45.

[23] Cloninger, C. R., Przybeck, T. R., Svrakic, D. M., \& Wetzel, R. D. (1994). The temperament and character inventory (TCI): A guide to its development and use. Center for Psychobiology of Personality, Washington University, St Louis, MO.

[24] Martins, N. (2002). A model for managing trust. International Journal of Manpower, 23(8), 754-769.

[25] Gunkel, M., Schlaegel, C., Langella, I. M., \& Peluchette, J. V. (2010). Personality and career decisiveness: An international empirical comparison of business students' career planning. Personnel Review, 39(4), 503-524.

[26] Nandan, T., \& Saurabh, K. (2016). Big-five personality traits, financial risk attitude and investment intentions: Study on Generation Y. International Journal of Business Forecasting and Marketing Intelligence, 2(2), 128-150.

[27] Durand, R. B., Newby, R., Peggs, L., \& Siekierka, M. (2013). Personality. The Journal of Behavioral Finance, 14(2), 116-133.

[28] Wilmer Foundation, Hong Kong. Sadi, R., Asl, H. G., Rostami, M. R., Gholipour, A., \& Gholipour, F. (2011). Behavioral finance: The explanation of investors' personality and perceptual biases effects on financial decisions. International Journal of Economics and Finance, 3(5), 234-241.

[29] Burns, P. C., \& Wilde, G. J. S. (1995). Risk taking in male taxi drivers: Relationships among personality, observational data and driver records. Personality and Individual Differences, 18(2), 267-278.

[30] Kiev, A. (2003). The psychology of risk: Mastering market uncertainty. United States: John Wiley \& Sons.

[31] Keller, C., \& Siegrist, M. (2006). Investing in stocks: The influence of financial risk attitude and values-related money and stock market attitudes. Journal of Economic Psychology, 27(2), 285-303.

[32] Wanyana, B. (2011). Investor awareness, perceived risk attitudes, and stock market investor behaviour: A case of Uganda securities exchange. Makerere University, Business School, Kampala (Unpublished doctoral dissertation).

[33] Wood, R., \& Zaichkowsky, J. L. (2004). Attitudes and trading behavior of stock market investors: A segmentation approach. The Journal of Behavioral Finance, 5(3), 170-179.

[34] Douglas, M., \& Wildavsky, A. (1982). Risk and culture: An essay on the selection of technical and environmental dangers. California: University of California Press.

[35] Lim, K. L., Soutar, G. N., \& Lee, J. A. (2013). Factors affecting investment intentions: A consumer behaviour perspective. Journal of Financial Services Marketing, Nature Publishing Group, 18(4), 301315.

[36] Fishbein, M., Jaccard, J., Davidson, A. R., Ajzen, I., \& Loken, B. (1980). Predicting and understanding family planning behaviors. Prentice Hall.

[37] Lo, S.-K., Wang, C.-C., \& Fang, W. (2005). Physical interpersonal relationships and social anxiety among online game players. Cyberpsychology \& Behavior, 8(1), 15-20.

[38] Noctor, M., Stoney, S., \& Stradling, R. (1992). National Westminster Bank. Washington: The Times.

[39] Jureviciene, D., \& Jermakova, K. (2012). The impact of individuals' financial behaviour on investment decisions. Electronic International Interdisciplinary Conference, 242-250.

[40] Mandell, L., \& Klein, L. S. (2009). The impact of financial literacy education on subsequent financial behavior. Journal of Financial Counseling and Planning, 20(1), 15-24.

[41] Hilgert, M. A., Hogarth, J. M., \& Beverly, S. G. (2003). Household financial management: The connection between knowledge and behavior. Federal Reserve Bulletin, 89, 309- 332.

[42] Bonte, W., \& Filipiak, U. (2012). Financial literacy, information flows, and caste affiliation: " Empirical evidence from India. Journal of Banking \& Finance, 36(12), 3399-3414.

[43] Kabra, G., Mishra, P. K., \& Dash, M. K. (2010). Factors influencing investment decision of generations in India: An econometric study. Asian Journal of Management Research, 308-326.

[44] Diacon, S. (2004). Investment risk perceptions: Do consumers and advisers agree? International Journal of Bank Marketing, 22(3), 180199.

[45] Weber, E. U., \& Milliman, R. A. (1997). Perceived risk attitudes: 
Relating risk perception to risky choice. Management Science, 43(2), $123-144$.

[46] Salehi, M., \& Mohammadi, N. (2017). The relationship between emotional intelligence, thinking style, and the quality of investors' decisions using the log-linear method. Qualitative Research in Financial Markets, 9(4), 325-336.

[47] Van Rooij, M. C., Lusardi, A., \& Alessie, R. J. (2012). Financial literacy, retirement planning and household wealth. The Economic Journal, 122(560), 449-478.

[48] Pedhazur, E. J. (1982). Multiple regression in behavioral research: Explanation and prediction. Fort Worth, TX: Holt, Rinehart and Winston.

[49] Ajzen, I. (1985). From intentions to actions: A theory of planned behavior. Heidelberg: Springer.

[50] Ajzen, I. (1991). The theory of planned behavior. Organizational Behavior and Human Decision Processes, 50(2), 179-211.

[51] Bailey, J. J., \& Kinerson, C. (2005). Regret avoidance and risk tolerance. Journal of Financial Counseling and Planning, 16(1), 2328.

[52] Bali, T. G., Demirtas, K. O., Levy, H., \& Wolf, A. (2009). Bonds versus stocks: Investors' age and risk taking. Journal of Monetary Economics, 56(6), 817-830.

[53] Barber, B. M., \& Odean, T. (2001). Boys will be boys: Gender, overconfidence, and common stock investment. The Quarterly Journal of Economics, 116(1), 261-292.

[54] Baron, R. M., \& Kenny, D. A. (1986). The moderator-mediator variable distinction in social psychological research: Conceptual, strategic, and statistical considerations. Journal of Personality and Social Psychology, 51(6), 1173-1182.

[55] Chang, C.-H. (2008). The impact of behavioral pitfalls on investors' decisions: The disposition effect in the taiwanese warrant market. Social Behavior and Personality: An International Journal, 36(5), 617-634.

[56] Corter, J. E., \& Chen, Y.-J. (2006). Do investment risk tolerance attitudes predict portfolio risk? Journal of Business and Psychology, 20(3), 369-381.

[57] Durand, R., Newby, R., Tant, K., \& Trepongkaruna, S. (2013). Overconfidence, overreaction and personality. Review of Behavioral Finance, 5(2), 104-133.

[58] Fellner, G., \& Maciejovsky, B. (2007). Risk attitude and market behavior: Evidence from experimental asset markets. Journal of Economic Psychology, 28(3), 338-350.

[59] Hallahan, T., Faff, R., \& McKenzie, M. (2003). An exploratory investigation of the relation between risk tolerance scores and demographic characteristics. Journal of Multinational Financial Management, 13(4-5), 483-502.

[60] Hunter, K., \& Kemp, S. (2004). The personality of e-commerce investors. Journal of Economic Psychology, 25(4), 529-537.

[61] Krishnan, R., \& Beena, F. (2009). Measurement of conformity to behavior finance concepts and association with individual personality. IUP Journal of Behavioral Finance, 6(3/4), 25-40.

[62] Olsen, R. A., \& Cox, C. M. (2001). The influence of gender on the perception and response to investment risk: The case of professional investors. The Journal of Psychology and Financial Markets, 2(1), 29 36.

[63] Ozmen, O., \& S * Umer, Z. H. (2011). Predictors of risk-taking behaviors among Turkish " adolescents. Personality and Individual Differences, 50(1), 4-9.

[64] Podsakoff, P. M., MacKenzie, S. B., \& Podsakoff, N. P. (2012). Sources of method bias in social science research and recommendations on how to control it. Annual Review of Psychology, 63, 539-569.

[65] Shleifer, A. (2000). Inefficient markets: An introduction to behavioural finance. Oxford University Press.

[66] Tang, T. L.-P. (2007). Income and quality of life: Does the love of money make a difference? Journal of Business Ethics, 72(4), 375-393.

[67] Williams, D. G. (1992). Dispositional optimism, neuroticism, and extraversion. Personality and Individual Differences, 13(4), 475-477.

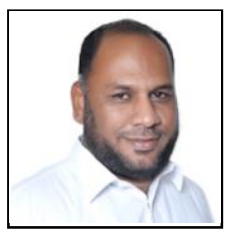

Javed Hussain is a $\mathrm{PhD}$ scholar at University of Karachi, Pakistan. He has more than 16 years of Academic \& Industry experience. This includes Teaching \& Research experience of more than 14 years with prestigious institutions like Mohammad Ali Jinnah University Karachi \& University of Karachi, Pakistan as Assistant Professor \& Adjunct Faculty respectively. His corporate experience includes Financial Consultancy as Financial Analyst to the leading brokerage houses of PSX. Awarded Two Consecutive Gold Medals for Standing First Class First Student in M. Com. (Finance) \& M.Phil. (Finance). He has also awarded Two Gold Medals for pride of performance (Teaching Finance) in the year $2013 \& 2015$.

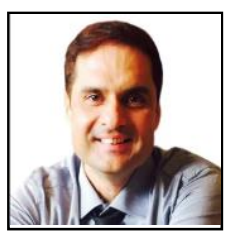

Tariq Mehmood Dar is a medical doctor. He earned his MBBS degree from Dow Medical College, Karachi University, Pakistan. He did his postgraduation in Diabetology. Dr. Tariq is a Clinical Research Certified Professional.

He also holds an MBA degree specialization in sales \& marketing. He is currently pursuing his MS in Management Sciences.

He has more than 15 years of sales and marketing experience in pharmaceutical industry in Pakistan \& UAE. He worked at different position in the pharmaceuticals from medical representatives to marketing head. Currently, he holds a position of Director Marketing \& Sales in a multinational pharmaceutical company based at UAE.

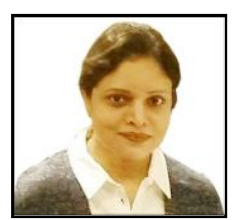

Neelofer Tariq is a professional pharmacist and seasoned marketer. She is a Doctor of Pharmacy. She earned Doctor of Pharmacy degree from Karachi University, Pakistan. She also holds an MBA degree with specialization in Pharmaceutical Marketing \& Health Management. She is currently pursuing her MS in Management Sciences.

She is a professional sales and marketing trainer and holds more than 10 years' experience in the pharmaceutical industry of Pakistan/UAE. 